\title{
Carbon isotope study of past 30,000 year BP using lake sediment
}

\author{
KAMINI BISHT AND BAHADUR SINGH KOTLIA
}

Kumaun University, Nainital

Presenting Author: kaminibisht.geo@gmail.com

A $336 \mathrm{~cm}$ core retrieved from the Dewar $\left(30^{\circ} \mathrm{N}\right.$ Lat. \& $79^{\circ} \mathrm{E}$ Long.)which is a water logged open swampy lake situated in the Chamoli district, Uttarakhand, India at an altitude of 1727 m.s.l generally comprising of silty sand, sandy silt and silt as major lithofacies showing variability in colour, thickness, fossil content and sedimentary structures. It records some major climatic events of the Pleistocene-Holocene epoch using carbon isotope $\left(\delta^{13} \mathrm{C}\right)$ and total organic carbon (TOC). The TOC shows a constant value $(0.1-0.4 \%)$ from bottom to large shift (more value) towards the top representing the role of detrital sedimentation and availability of moisture in the study area. The carbon isotope $\left(\delta^{13} \mathrm{C}\right)$ shows variability from bottom to top ranging from -16.4 to $-29.2 \%$. The $\delta^{13} \mathrm{C}$ values shows the presence of $\mathrm{C} 3$ and $\mathrm{C} 4$ plant species representing climatic conditions prevailing in the area. Based on the values of carbon content and TOC, the core is divided into zones which shows presence of warm and cold events that affected the area with recording the major events like Heinrich (H), Last glacial maxima (LGM), Younger Dryas (YD) and $8.2 \mathrm{kyr}$ event. 